\title{
El uso y tratamiento de la terminología en El Trajumán de M. Papo (1884)
}

\author{
Carsten Sinner* \\ Universität Leipzig \\ ORCID ID: https://orcid.org/0000-0002-5394-7041 \\ Encarnación Tabares Plasencia** \\ Universität Leipzig \\ ORCID ID: https://orcid.org/0000-0003-2491-1901 \\ Elia Hernández Socas*** \\ Universidad de La Laguna \\ ORCID ID: https://orcid.org/0000-0001-9800-8243
}

La finalidad de este trabajo es presentar la terminología empleada por Michael Papo en su obra El Trajumán o libro de converśación en español y alemán (nemŝesco) por provecho de muchos siñores del Oriente que viajan a_la Nemsîa recoǵido de los mijores libros de converśación que hay en ditas lenguas por el minor: Menahem b. Michael Papo, publicada en Viena en 1884, y efectuar un análisis lingüístico de la misma, poniendo el foco (a) en la variación de estas unidades en la obra y en las causas que se hallan tras dicha variación y (b) en una clasificación de la terminología constatada. Para ello, tomaremos el marco teórico de la lingüística variacional y nos valdremos metodológicamente de las nuevas herramientas que la lingüística del texto ha puesto a disposición del análisis textual.

Palabras Clave: literatura sefardí aljamiada; terminología; Michael M. Papo; el judeoespañol de Viena; contacto lingüístico alemán-judeoespañol.

The Use and Treatment of Terminology in Papo's El Trajumán.- The purpose of this contribution is to present the terminology used by Michael Papo in his travel guide $E l$ Trajumán o libro de converśación en español y alemán (nemŝesco) por provecho de muchos siñores del Oriente que viajan a_la Nemŝia recogído de los mijores libros de converśación que hay en ditas lenguas por el minor: Menahem b. Michael Papo published in 1884 in Vienna. The focus of the linguistic analysis is (a) on the variation of these units on the book and on the reasons for this variation and (b) on a classification of the terminology. To this end, we will take the theoretical approach of variational linguistics and make methodological use of the new tools that text linguistics has made available for textual analysis.

\footnotetext{
*sinner@uni-leipzig.de

** tabares@uni-leipzig.de

***ehernaso@ull.es
}

Copyright: (C) 2020 CSIC. Este es un artículo de acceso abierto distribuido bajo los términos de la licencia de uso y distribución Creative Commons Reconocimiento 4.0 Internacional (CC BY 4.0). 
KeYwords: Sephardic literature; Terminology; Michael M. Papo; Judeo-Spanish of Vienna; German-Judeo-Spanish Language Contact.

\section{INTRODUCCIÓN}

En el presente trabajo seleccionamos varias áreas de especialidad empleadas por Michael Menahem Papo en su obra decimonónica El Trajumán o libro de converśación en español y alemán (nemŝesco) por provecho de muchos siñores del Oriente que viajan a_la Nemsía ${ }^{1}$ recogíido de los mijores libros de converśación que hay en ditas lenguas por el minor: Menahem b. Michael Papo (Wien: Jacob Schlossberg, 1884), con el fin de abordar el tratamiento terminológico que se le confiere a dichos ámbitos. Para ello, nos encargaremos de extraer el material terminológico haciendo uso de las herramientas proporcionadas por la lingüística textual para su vaciado $\mathrm{y}$, acto seguido, llevamos a cabo un análisis lingüístico-filológico, con el objetivo de (a) estudiar la variación de estas unidades en la obra intentando escudriñar las causas que puedan explicar tal variación y (b) clasificar tales unidades de acuerdo con los principios que guían el ámbito de la terminología en la lingüística moderna. Con nuestro trabajo pretendemos contribuir a los estudios lexicográficos y terminológicos del judeoespañol aplicando nociones teóricas y herramientas metodológicas hasta ahora no aplicadas lo suficiente en el estudio del judeoespañol, siguiendo así el camino iniciado por Schmid con el proyecto de investigación UniBas 2014 de la Universidad de Basilea, que supuso la introducción de la lingüística de corpus en los estudios sefardíes, y por García Moreno y Pueyo Mena con la creación de corpus históricos del judeoespañol ${ }^{2}$. Para ello, en lo que respecta al

1 Aunque el autor no acentúa la palabra mediante el uso de «varicas», como sí hace en otras ocasiones, seguramente la forma correcta haya sido la acentuada, pues si nos fijamos en otros nombres de países formados sobre el mismo sufijo como Bulgaría (Joseph Nehama, Dictionnaire du Judéo-Espagnol [Madrid: CSIC, 1977] pág. 101) o Turkía (Nehama, Dictionnaire, pág. 569), todo parece indicar que se trate de la forma con hiato Nemŝía.

2 Efectivamente, uno de los trabajos que más destaca por la incorporación de tales herramientas es el Corpus Histórico del Judeoespañol (CORHIJE = Aitor GARCía MoReno y Francisco Javier Pueyo Mena, Corpus Histórico Judeoespañol [en línea], $<$ http://esefardic.es/corhije $>$ [última consulta: 22/04/2020]. Mediante la creación de este 
estudio de la variación terminológica que muestra la obra de Papo, adoptaremos, por un lado, el enfoque de la lingüística de variedades ${ }^{3}$, que ya hemos empleado con éxito en otros trabajos sobre fraseología del español ${ }^{4} \mathrm{y}$, por otro, retomaremos los postulados teóricos de la socioterminología que aplicaremos para analizar algunos de los ámbitos de especialidad que trata Papo en su obra 5 .

\section{LA OBRA Y SU AUTOR}

La obra analizada se publicó en Viena -más adelante se verá la importancia de este dato- en el último cuarto del siglo XIX, se encuentra escrita en judeoespañol y alemán, en alfabeto hebreo con escritura rasí. Precisamente, este último hecho nos ha animado a realizar una edición transcrita ${ }^{6}$ y comentada de la obra de Papo que data de 1884. Su título

corpus en línea se ha abierto una nueva vía de investigación que permitirá realizar nuevos trabajos sobre el judeoespañol con metodología propia de la lingüística de corpus. Véanse también, entre otros, los trabajos de Ángel Berenger AmAdor, "Acerca del gerundio en español», en Lengua, Llengua, Llingua, Lingua, Langue. Encuentros filológicos (ibero)románicos. Estudios en homenaje a la profesora Beatrice Schmid, eds. Yvette Bürki, Manuela Cimeli y Rosa SÁnchez (München: Peniope, 2012) págs. 33-40; Rosa SÁNCHEZ, «Consideraciones para la forja de un registro metateatral judeoespañol», en Llingua, Lingua, Langue. Encuentros filológicos (ibero)románicos. Estudios en homenaje a la profesora Beatrice Schmid, eds. Yvette BüRKI, Manuela Cimeli y Rosa SÁnchez (München: Peniope, 2012) págs. 390-407, y Sandra Schlumpf, Condicionalidad y concesividad en judeoespañol moderno escrito. Teoría y análisis de corpus (Lausanne: Sociedad Suiza de Estudios Hispánicos, 2015).

${ }^{3}$ En el sentido que se explica y desarrolla en el manual de Carsten Sinner, Varietätenlinguistik: Eine Einführung (Tübingen: Narr, 2014).

${ }^{4}$ Carsten Sinner y Encarnación Tabares Plasencia, «El problema de las variantes fraseológicas desde la perspectiva de la Lingüística de Variedades», Revista de lingüística teórica y aplicada 54:2 (2016) págs. 13-41.

5 Tal y como ha sido concebida por François GAUdin, Socioterminologie: Une approche sociolinguistique de la terminologie (Bruxelles: Duculot, 2003).

${ }^{6}$ Como se indica en Elia Hernández Socas, Carsten Sinner y Encarnación TabaReS Plasencia, «El Trajumán de Michael Papo 1884», en Los sefardies ante los retos del mundo contemporáneo. Identidad y mentalidades, eds. Paloma Díaz-Mas y María SÁnChez PÉrez (Madrid: CSIC, 2010) págs. 333-344: 334, nota 2, se ha utilizado para la transcripción de este texto aljamiado el sistema ideado por Iacob M. HassáN, «Transcripción normalizada de textos judeoespañoles», Estudios Sefardies 1 (1978) págs. 147- 


\section{ya nos avanza que su finalidad era fundamentalmente práctica ${ }^{7}$ : proveer de una herramienta que facilitara la comunicación en territorios germa-}

150. Sin embargo, en ocasiones, hemos debido adaptarlo a las características específicas de la obra, dado que no solo contiene texto en romance, sino en alemán, lengua para la que, en principio, no se había planteado la escritura rasí. Sobre las dificultades de reproducir en rasí la lengua alemana, el propio Papo indicaba: «Al leedor (meldador). Hay tiempo, que muchos señores del Oriente viajantes por la Nemŝia, deśean un librico semejante por darsen algo a entender. Y aun_que es muy difícil (fuerte) de conponerlo, tanto de parte del español que está mezclado en cada provincia de la Turquía con la habla de aquel país, como también de parte del alemano (nemsesco) que no se puede pronunciar cumplidamente con la letra ladina (raší), con todo reśolví por inĝeniarlo con procurar de reformar todo lo posible por que sea entendido. Por ello se roga de atinar bien estas reglas antes de pasar adelante» (la cursiva es nuestra) (PAPO, El Trajumán, pág. III). Con respecto a las disfunciones entre la lengua hablada por los sefardíes diferente del hebreo en la diáspora y su intento de reproducción en alifato, resultan muy sugestivas las palabras de LLEal para introducir uno de los motivos que pudieron facilitar que el judeoespañol fuera por derroteros diferentes al del español peninsular escrito: «El uso de un sistema gráfico distinto los apartó progresivamente de la norma del español escrito que, por esos años, se estaba configurando en la península. Quienes escribían intentaban reproducir, mediante caracteres hebraicos, los sonidos de la lengua hablada. Sus vacilaciones, en los primeros tiempos, no procedían exclusivamente de la inadecuación de las grafías para la representación de una lengua románica, sino también, y me atrevería a decir fundamentalmente, de la inexistencia de una «imagen gráfica» que se asociara a la «imagen acústica» y definiera así su contorno. La relación dialéctica que se daba en España entre lengua hablada y norma de la lengua escrita no actuaba entre los judíos de la diáspora»; $c f$. Coloma Lleal, El judezmo: El dialecto sefardí y su historia (Barcelona: Universidad de Barcelona, 1992) pág. 203. Y volviendo a las particularidades que nos han obligado a adaptar el sistema de transcripción hemos de mencionar el hecho de que el texto aljamiado aparezca, en su mayor parte, vocalizado mediante el uso de un punto debajo de las yod y la vav para marcar la [i] y la [u] respectivamente, tanto en las partes en alemán como en judeoespañol, o también el uso de «varicas»o comillas rectas a modo de tildes con las que, de manera bastante inconsistente, el autor marca si la palabra es oxítona, paroxítona o proparoxítona. Aparte de esto, puesto que el autor tiene que adaptar la escritura aljamiada a la fonética del alemán, el texto presenta algunas particularidades como, por ejemplo, el uso de la letra hé para representar el fonema fricativo glotal sordo /h/. En la edición comentada que estamos preparando de la obra dedicamos un capítulo extenso a explicar el sistema de transcripción empleado.

${ }^{7}$ La palabra trajumán 'intérprete (|| persona que explica lo dicho en otra lengua)' $(D L E=$ Real ACAdemia Española y Asociación de ACAdemias de la Lengua EspaÑolA, Diccionario de la lengua española [23. ${ }^{\mathrm{a}}$ ed., versión 23.2 en línea], <https://dle. rae.es $>$, s.v. trujamán) que encontramos en el texto no se derivaría directamente de la voz originaria árabe tur ğumān sino de una forma turca tar ğumán o tražumán; cf. Hernández Socas, Sinner y Tabares Plasencia, «El Trajumán», pág. 335, nota 3. 
nohablantes ${ }^{8}$ a los sefardíes provenientes de las comunidades situadas en áreas geográficas que habían formado o formaban parte del Imperio Otomano, fundamentalmente de ciudades turcas ${ }^{9}$. La fijación del año de publicación de la obra (1884, y no 1844 como se indica en la portada de la propia obra) constituyó un escollo, que pudo salvarse, en parte, gracias a los datos biográficos de su autor ${ }^{10}$.

En el título encontramos igualmente una referencia vaga a las posibles fuentes empleadas por el autor para elaborar la obra, pues se señala que ha sido «recoǵido de los mijores libros de converśación que hay en ditas lenguas», esto es, parece que utilizó otras guías de conversación, pero no menciona ninguna explícitamente. La denominada Quellenforschung 'investigación de las fuentes' es de gran interés para el conocimiento cabal de una obra, pero, a la vez, puede resultar una labor muy

8 Aunque en el título emplee un genérico Nemŝia, en relación con el Imperio austrohúngaro, al que más tarde aludirá como Austria-Hungaria (pág. 79), el autor se refiere, fundamentalmente, a Viena, como se desprende de la información que ofrece sobre la ciudad en la obra (págs. 81-88). Cf. Samuel Romano (Dictionary of Spoken JudeoSpanish/French/German [Jerusalem: Hakeshet, 1995 \{1933\}] pág. 253) que da nimcésko, nemcesko 'allemand' o Nehama, Dictionnaire du Judéo-Espagnol, pág. 382, que trae némsi, del turco nemse 'autrichien'.

9 La mención a los «siñores del Oriente» en el título de la obra parece indicarlo. Además, en el fragmento de la obra citado anteriormente y consignado en la nota 3 de este trabajo puede leerse: «Y aun_que es muy difícil (fuerte) de conponerlo, tanto de parte del español que está mezclado en cada provincia de la Turquía con la habla de aquel país, ...» (PAPO, El Trajumán, pág. III). Tampoco puede descartarse que haga referencia a los sefardíes de otras localidades que habían estado bajo el dominio del Imperio Otomano, pues no parece que la mención a la variación dialectal dentro del judeoespañol esté relacionada solo con Turquía («tanto de parte del español que está mezclado en cada provincia de la Turquía», en PAPO, El Trajumán, pág. III). Además, durante todo el siglo XIX, Viena se convierte en un centro intelectual sefardí muy importante y un gran número de sefardíes de las comunidades balcánicas se desplazará a esta ciudad, siendo que muchos de ellos se asientan definitivamente en ella; $c f$. Aldina Quintana RodRíGUEZ, «Variación diatópica en judeoespañol», Revista Internacional de Lingüística Iberoamericana 8 (2006) págs. 77-97: 94, y Michael Studemund-HaLévy y Gaëlle Collin, «Sefarad sur les rives du Danube. Vienne et la littérature judéo-espagnole», Miscelánea de Estudios Árabes y Hebraicos. Sección Hebreo 57 (2008) págs. 149-211.

$10 C f$. para más detalles Hernández Socas, Sinner y Tabares Plasencia, «El Trajumán», págs. 335 y 336. 
ardua ${ }^{11}$. Para ello, se comparan línea por línea con nuestra obra las guías de conversación en alemán y español (con otras lenguas, respectivamente) aparecidas antes de la aquí tratada para averiguar de dónde Papo podría haberse inspirado o haber copiado algo. En este sentido, un aspecto muy importante que estamos dilucidando es si Papo se limitó a textos bilingües en la combinación español-alemán o de estas lenguas con otras; además, la alusión al «español» puede resultar también ambigua en el título: ¿se refiere a la norma peninsular o al judeoespañol? Si atendemos a lo que nos dice el autor en las páginas introductorias y al material recogido en Papo, así como al trasfondo ideológico de Papo ${ }^{12} \mathrm{y}$ otros intelectuales sefardíes vieneses en lo que atañe al judeoespañol, parece que debe de tratarse, por lo menos, en parte, del español peninsular.

En cuanto a la estructura y contenido de la guía, sin entrar en pormenores para los que se remite a Hernández Socas, Sinner y Tabares Plasencia ${ }^{13}$, lo más destacable es que cuenta con 112 páginas (96 numeradas en arábigos y 16 en romanos). En las 16 primeras páginas, con numeración romana, se recoge, en primer lugar, una especie de «guía de uso», donde Papo informa al lector de las decisiones que ha tomado para

$11 C f$. M. a Ángeles García Aranda, en su estudio de la obra de Emanuel del Mar («La evolución de las nomenclaturas del español: el Vocabulario de las voces más usuales (1839) de Emanuel del Mar», en El diccionario como puente entre las lenguas y culturas del mundo: actas del II Congreso Internacional de Lexicografía Hispánica, coords. Dolores Azorín Fernández et al. [Biblioteca Virtual Miguel de Cervantes, 2008] págs. 89-95: 94), quien se encontró con dificultades análogas a las que aquí presentamos, como explicaremos más adelante.

12 En la cita que sigue, PAPO (El Trajumán, pág. III, en la transcripción de la edición que nos encontramos preparando) parece indicar, estableciendo un juicio de valor, que va a hacer uso por regla general del español peninsular, admitiendo que, para facilitar su intelección, empleará glosas («cerrado con medias lunas») donde introducirá la palabra o expresión propiamente judeoespañolas: «La habla ešpañol de dito librico, generalmente es la verdadera. Y por muchas palabras que no son conocidas, topará el meldador a_lado (cerrado con medias lunas) cómo la uśan muchos a hablar, o al_cabo del libro de hoja 89. [sic] adelantre en la tabla de declaro a_la regla álef-bet según la letra primera de aquella palabra». Sobre las glosas de Papo en la obra y sus funciones, remitimos a Elia Hernández Socas, Carsten Sinner y Encarnación Tabares Plasencia, «La función de las glosas en El Trajumán de Michael Papo (1884)», Zeitschrift für romanische Philologie 130:2 (2014) págs. 397-429.

13 Hernández Socas, Sinner y Tabares Plasencia, «El Trajumán». 
la adecuación al alfabeto hebreo de determinados fenómenos fónicos y gráficos del alemán. Es un apartado muy interesante por las formas que emplea el autor para hacer las descripciones lingüísticas. Un ejemplo de este tipo de indicaciones lo encontramos en el siguiente fragmento ${ }^{14}$ :

\section{Las letras ה ה [ כ כ כ ד דaf [kaf final].}

$\mathrm{La}$ [ [hé] sierve en nemŝesco por letra en cada lugar de la palabra (no como en la letra ladina que sierve por $\boldsymbol{x}$ [álef] solo al_cabo). Su pronuncia (meldadụra) no es igual cụmo [sic] la $\aleph$ [álef], otro que más floja (salida de más adientro de la garganta, según saven diferenciar muchos y en lašón hacodeš de $x$ [alef] a $ה$ [hé]. Esto prime atinado por entender la palabra. Por eǰemplo: Hader andrajo. Ader vena.

La $\supset[k a f]\urcorner[k a f$ final $]$. Onde se topan estas letras es señal que no se pronuncia igual como a $\pi[$ het $]$ otro que algo semejante a_la 7 ' $[$ yod $]$. Por ejemplo: ịch yo. reịch rịco. sprechen hablar ${ }^{15}$.

Asimismo, ofrece unos apuntes de gramática alemana (artículo, pronombres, tiempos verbales ${ }^{16}$, orden de palabras, etc.) y el índice de contenidos, que se inicia en las páginas numeradas en arábigos. Estas últimas se dividen en tres partes principales (dos de ellas de carácter lingüístico) y un anexo: la primera (págs. 1-49), estructurada en ocho capítulos, recoge el léxico más usual en alemán, de acuerdo con su categoría gramatical. El más amplio de los capítulos es el dedicado a los sustantivos, donde, a su vez, se efectúan subdivisiones por ámbitos designativos ${ }^{17} \mathrm{o}$ campos nocionales ${ }^{18}$; una segunda parte

${ }^{14} C f$., en este contexto, la obra de Amor Ayala, Los sefardies de Bulgaria. Estudio y edición crítica de la obra «Notas istorikas» de Avraam Moshe Tadjer (Berlin-Boston: De Gruyter, 2017) págs. 296-297, en la que también trata el uso de hé $<\pi>$ para representar la fricativa glotal sorda $[\mathrm{h}]$.

15 PAPO, El Trajuman, pág. IV.

${ }^{16}$ En relación con el tratamiento dispensado por Papo a los tiempos verbales en $\mathrm{El}$ Trajumán, remitimos a Encarnación Tabares Plasencia, Carsten Sinner y Elia HerNÁNDEZ Socas, «La expresión del tiempo en El Trajumán de Michael Papo (Viena, 1884)», en Tiempo y espacio y relaciones espacio-temporales en judeoespañol, eds. Yvette BÜrKI y Carsten Sinner (München: Peniope, 2012) págs. 63-76.

17 Cf. García Aranda, «La evolución de las nomenclaturas del español», pág. 89, habla de «ámbitos designativos».

18 Por su parte, en el trabajo pionero de Marta Concepción Ayala Castro, «El concepto de nomenclatura», Actas del IV Congreso Internacional EURALEX'90 (Barce- 
(págs. 51-78) ${ }^{19}$ presenta diferentes situaciones comunicativas a las que el viajero tendría que enfrentarse durante su estancia en tierras germánicas; en estas partes encontramos mucha terminología de diferentes ámbitos de especialidad, como la medicina, la banca (tipos de cambio, etc.) o la moda (nombres de telas, etc.); una tercera parte sin carácter lingüístico (págs. 79-88) recopila información y recomendaciones de utilidad al viajero (documentación necesaria, moneda, medios de transporte locales, etc.) (con más aspectos claramente clasificables como de especialidad) y luego acaba con una suerte de «guía turística» sobre la ciudad de Viena. Por último, en el anexo (págs. 89-96), se consignan unas tablas alfabéticas de léxico utilizado en la obra que requería de aclaración por parte del autor. En las partes lingüísticas, Papo comienza formalmente siempre con el judeoespañol para, acto seguido, ofrecer la correspondencia en alemán de todas las unidades tanto mono como pluriverbales que se hallan en Papo.

El autor de nuestra obra, Michael M. Papo, nació en Sarajevo el 15 de diciembre de $1843^{20}$ y falleció el 29 de enero de 1918 en Viena (de ahí que hayamos excluido el año 1844 como fecha de edición de la obra). Otras fuentes ${ }^{21}$ coinciden en el dato de que fue rabino de la comunidad israelita española de Viena; Studemund-Halevy y Collin ${ }^{22}$ completan

lona: Bibliograf, 1990) págs. 437-454: 439, se emplea el término «campos nocionales».

19 En la página 50, antes comenzar la segunda parte, Papo introduce un índice de abreviaturas empleadas y una aclaración sobre la transcripción al rasí de los sonidos vocálicos alemanes $[\varepsilon],[\varnothing]$ y $[\mathrm{y}]$.

${ }^{20}$ Según el testimonio que nos proporciona Renate HeuER, Bibliographia Judaica: $L-R$, vol. 2 (Frankfurt am Main: Campus Verlag, 1984).

${ }^{21}$ Concretamente, Chaim David LiPPE, Bibliographisches Lexicon der gesammten jüdischen Literatur der Gegenwart und Adress-Anzeiger: ein lexicalisch geordnetes Schema mit adressen von Rabbinen, Predigern, Lehrern, Cantoren, Schriftstellern, Freunden und Förderern der jüdischen Literatur in der alten und neuen Welt (Wien: Löwy, 1881) pág. 358; Meyer KaYserling, Biblioteca española-portugueza-judaica (Pamplona: Analecta, 2001 [1890]) pág. 84, y Salomon WinInger, Große Jüdische National-Biographie mit nahezu 13.000 Lebensbeschreibungen namhafter jüdischer Männer und Frauen aller Zeiten und Länder. Ein Nachschlagewerk für das jüdische Volk und dessen Freunde, vol. 4 (Czernowitz: Tip. Arta, 1929) pág. 605.

22 Studemund-Halevy y Collin, «Sefarad sur les rives du Danube», págs. 149211.

SEFARAD, vol. 80:2, julio-diciembre 2020, págs. 479-509. ISSN: 0037-0894. https://doi.org/10.3989/sefarad.021-013 
esta información señalando que constituyó, además, una figura muy influyente en esta comunidad. Posiblemente, por sus orígenes bosnios, debió de ocupar un puesto de relevancia como mediador entre grupos de judíos sefardíes de los Balcanes, llegados a Viena en el último tercio del siglo XIX, y la sociedad judía de esta ciudad. En la obra que nos ocupa también se puede verificar su posicionamiento ideológico en torno al judeoespañol, como ya hemos indicado supra y concretaremos más adelante, en el apartado cuarto de este trabajo. Aparte de El Trajumán, solo nos consta la existencia de dos obras más que puedan atribuirse a su autoría -ambas publicadas en Viena-: una traducción al judeospañol (en rasí) de la obra de Adolf von Zemlinsky, Geschichte der türkischisraelitischen Gemeinde zu Wien, von ihrer Gründung bis heute ${ }^{23}$ o sea, una 'Historia de la comunidad turco-israelita de Viena desde sus orígenes hasta el presente' y una edición del Séder Tefilá, libro de oraciones cotidianas judías, de $1908^{24}$.

3. Viena COMO CENTRO LiNGÜÍstico y CULTURAL SEFARDí. LA AMPLIACIÓN Y REHISPANIZACIÓN DEL JUDEOESPAÑOL

En su monografía sobre la variación geográfica en judeoespañol, Quintana Rodríguez habla de comunidades sefardíes en situación especial, y, concretamente, se refiere a las de Egipto y Viena ${ }^{25}$. La «especialidad» se derivaría del problema de encuadre de estas dos zonas dentro del marco de la variación diatópica del judeoespañol, dado que se trata de comunidades secundarias creadas como extensión de comunidades primarias. Específicamente, por lo que a Viena se refiere, indica la lingüista que, a pesar de acoger a sefardíes de áreas dialectales muy dispa-

${ }^{23}$ Wininger, Große Jüdische National-Biographie..., pág. 605, y Heuer, Bibliographia Judaica, pág. 149.

24 Studemund-Halévy y Collin, «Sefarad sur les rives du Danube», pág. 179.

25 Vid. Aldina Quintana RodríGUEZ, Geografía lingüistica del judeoespañol: estudio sincrónico y diacrónico (Bern: Peter Lang, 2006) págs. 126-127 y también sus otros trabajos «Geografía lingüística del judeoespañol de acuerdo con el léxico», Revista de Filología Española 82:1-2 (2002) págs. 105-138 y «Diatopische Variation des Judenspanischen in den Balkanländern und in der Türkei», Neue Romania 19 (1997) págs. 4765. 
res, los datos de que se disponen apuntan a que no se produjo un proceso de nivelación semejante a los ocurridos en la etapa formativa del judeoespañol. En otro trabajo, ya mostramos que este aserto de Quintana Rodríguez debe matizarse y que, efectivamente, sí se dieron las condiciones para una koineización ${ }^{26}$. Por lo demás, Quintana Rodríguez destaca el dinamismo cultural de esta comunidad y el compromiso de sus intelectuales por determinar el papel que debía ocupar el judeoespañol en la sociedad sefardí ${ }^{27}$. Como hemos destacado en otro trabajo ${ }^{28}$, la época en la que se halla fechada nuestra obra es conocida por el debate que se dio en torno a la función identitaria del judeoespañol: ¿debía seguir usándose el judeoespañol como lengua cotidiana o debía abandonarse en favor de las diferentes lenguas nacionales donde se hallaban las distintas comunidades sefardíes? ${ }^{29}$. Y, precisamente, como apunta Quintana Rodríguez ${ }^{30}$, Viena había sido un importante centro de discusión: el hecho de que el alemán fuera lengua de cultura del Imperio austrohúngaro y que la burguesía judía balcánica enviara a estudiar a sus hijos a la Universidad de Viena generó la discusión de si era mejor asumir el alemán como lengua de cultura (como había ocurrido en otras comunidades con el francés) o conservar el judeoespañol modernizándolo mediante un proceso de acercamiento lingüístico al español peninsular del momento, lo que se conoce como recastellanización ${ }^{31} \mathrm{o}$, de forma más generalizada, rehispanización. Ese debate se produce en toda la comu-

${ }^{26}$ Carsten Sinner, Elia Hernández Socas y Encarnación Tabares Plasencia, «En torno a la influencia del alemán en el judeoespañol», Conferencia presentada en el XXII. Deutscher Hispanistentag, Berlín, 27-31 de marzo de 2019; presentado para su evaluación en el volumen editado por Laura Minervini y Frank SAVELSBERG (Leiden: Brill) en la colección Brill's Studies in Language, Cognition and Culture.

27 Quintana RodríGuez, Geografía lingüística, págs. 218-219.

28 Carsten Sinner, Elia Hernández Socas y Encarnación Tabares Plasencia, «Trazos ideológicos en El Trajumán de Michael Papo», Boletín Hispánico-Helvético 23 (2014) págs. 247-271.

29 Studemund-Halevy y Collin, «Sefarad sur les rives du Danube», pág. 151.

30 Quintana RodríGuez, Geografía lingüistica, pág. 129.

31 Aldina QUINTANA RoDRÍGUEz habla de rehispanizar en «Proceso de recastellanización del Judesmo», en Jewish Studies at the turn of the 20th century: Proceedings of the sixth EAJS congress, Toledo, 1998, eds. Judith Targarona Borrás y Ángel SáEnz BARDILlos, vol. 2 (Leiden: Brill, 1999) págs. 593-602. 
nidad internacional sefardí, en los diferentes países balcánicos ${ }^{32}$, pero parece que Viena se convirtió en uno de los baluartes rehispanizadores, además de en uno de los centros intelectuales y culturales más importantes del mundo sefardí en el siglo XIX ${ }^{33}$. Prueba de ello es la obra de Papo en la que se emplean formas patrimoniales judeoespañolas así como variantes del castellano moderno. Igualmente se recogen las apreciaciones del autor acerca del español de las que hemos hecho mención en diversos lugares de este trabajo. Papo, como otros autores de su época y de su ideología, parece querer ampliar el judeoespañol escrito para hacerlo apto para nuevos tipos textuales, nuevos géneros, echando mano de variantes diatópicas, diastráticas y diafásicas como también de elementos del castellano peninsular ${ }^{34}$.

\section{LA TERMinOlOGÍA EN EL TRAJ́UMÁN}

Tanto en la primera parte del libro, que constituye una especie de «Guía de Uso», como en la segunda, dividida en ocho capítulos, donde se alista un conjunto bastante numeroso de unidades léxicas judeoespañolas distribuidas por ámbitos designativos con sus correspondientes equivalencias en alemán, hallamos abundantes unidades terminológicas propias de diferentes dominios de especialidad como la gramática, la anatomía, la confección, la administración, etc. Este léxico especializado aparece, muchas veces, con glosas, donde se recogen variantes de la entrada principal. Precisamente, en ello nos centraremos en este trabajo.

\subsection{Metodología}

Para presentar el conjunto de la terminología empleada por Papo en esta obra y efectuar un análisis lingüístico de la misma, poniendo el foco

$32 C f$. Beatrice Schmid, «La lengua sefardí en su plenitud», en Sefardies: literatura y lengua de una nación dispersa, ed. Elena Romero (Cuenca: Ediciones de la Universidad de Castilla-La Mancha, 2008) págs. 51-79.

33 Quintana Rodríguez, Geografía lingüistica, pág. 123.

34 Sinner, Hernández Socas y Tabares Plasencia, «Trazos ideológicos». 
(a) en la variación de estas unidades en el libro y en las causas que se hallan tras dicha variación y (b) en una clasificación de la terminología constatada, hemos adoptado el enfoque de la lingüística de variedades ${ }^{35}$, que ya ha dado sus frutos en otros trabajos sobre fraseología del español ${ }^{36}$, y hemos operado de la manera desglosada a continuación.

Una vez transcrito el texto, lo hemos cargado en formato txt. en un software libre de análisis textual, AntConc, de Laurence Anthony ${ }^{37}$. Aplicamos la denominada stopword list de palabras gramaticales ${ }^{38}$ para obtener, en la medida de lo posible, solo unidades léxicas. Tras haber obtenido la lista de palabras, extraemos los ítems susceptibles de ser catalogados como término y sus variantes en la obra analizada. Como avanzábamos en la introducción, nuestra consideración de término viene determinada por los postulados de la socioterminología, tal y como ha sido concebida por Gaudin ${ }^{39}$, y de la teoría comunicativa de la terminología ${ }^{40}$, autores que proponen como ya señalara Alpízar Castillo que:

[e]l término es tan signo lingüístico como cualquier unidad léxica de las áreas no especializadas, y los hablantes científicos y técnicos son tan

${ }^{35}$ Como decíamos en la introducción, nos basamos en el trabajo ya mencionado de SINNER, Varietätenlingüistik.

36 Véase el trabajo ya mencionado de Sinner y TABAres Plasencia, «El problema de las variantes fraseológicas».

37 Laurence Anthony, AntConc, <https://www.laurenceanthony.net/software/ antconc/>, (última consulta: 22/08/2019).

38 Cf. Jacques SAVoY, «Stopword list in Spanish (351 words in Smart)», <http:// members.unine.ch/jacques.savoy/clef/spanishSmart.txt> (última consulta: 22/07/2019).

39 GAUDIn, Socioterminologie.

40 Véanse los trabajos de M. ${ }^{a}$ Teresa CABRÉ, La terminología: representación y comunicación. Una teoría de base comunicativa y otros artículos (Barcelona: IUL, 1999) y de M. ${ }^{\text {a }}$ Teresa CABré y Rosa EstopÀ, «El conocimiento especializado y sus unidades de representación: diversidad cognitiva», Sendebar 13 (2002) págs. 141-153. La teoría comunicativa de la terminología (TCT) de Cabré considera que los lenguajes especializados no son diferentes de la lengua general. Realmente estamos ante un sistema lingüístico dado que presenta diferentes valores dependiendo de las situaciones de comunicación. Una unidad léxica cualquiera activa su valor terminológico en el empleo particular que se da en un contexto comunicativo determinado. Asimismo, los contextos comunicativos pueden tener mayor o menor nivel de especialización de acuerdo con la perspectiva con la que se trate el tema, los destinatarios y los emisores de la comunicación, etc. 
hablantes como el resto. Las diferencias entre "término" y "no término" son de tipo pragmático, no formal, funcional ni semántico ${ }^{41}$.

Una vez establecidas las unidades terminológicas, hemos procedido a clasificarlas por dominios de especialidad. En algunas ocasiones, el autor mismo nos da la pista de estos ámbitos especializados, dado que

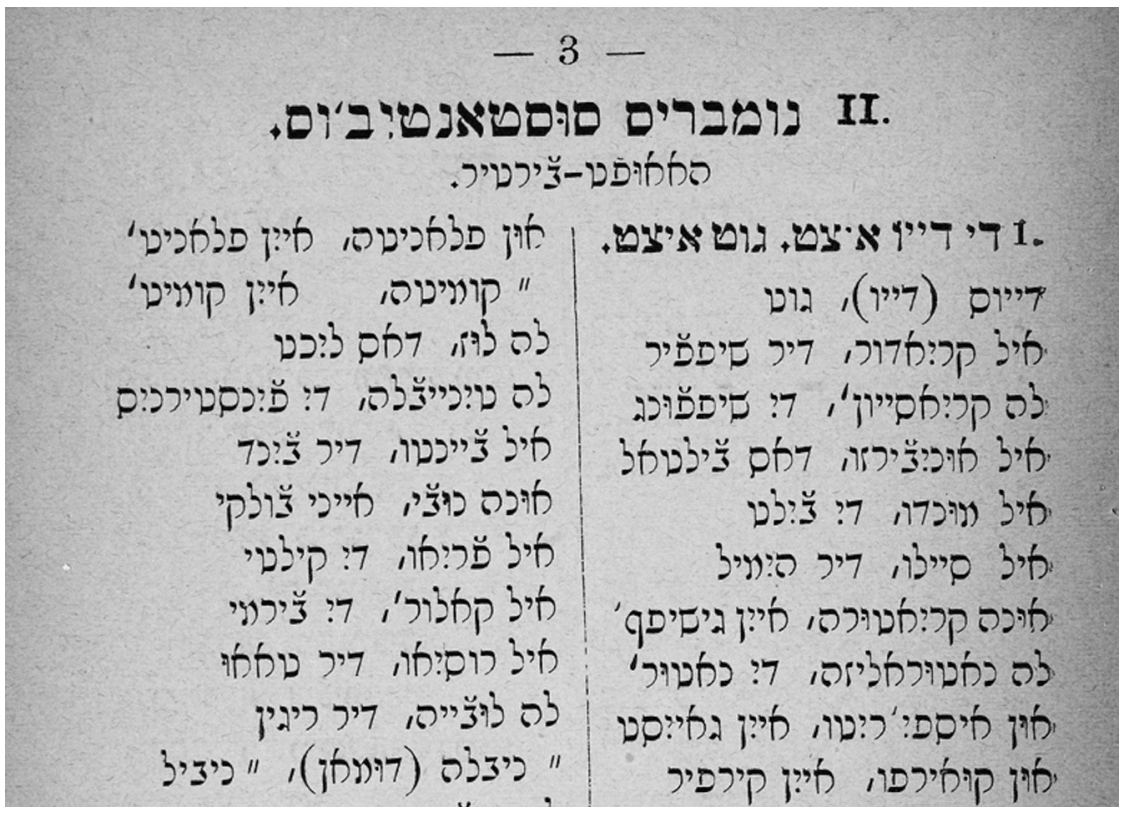

Fig. 1. Extracto de El Trajumán (pág. 3): Nombres sustantivos / De Dio

${ }^{41}$ Rodolfo Alpízar Castillo, ¿Cómo hacer un diccionario cientifico técnico? (Buenos Aires: Memphis, 1997) pág. 8. Precisamente, son las características pragmáticas de nuestro texto las que nos han hecho hablar de terminología en la obra. Los contextos en los que se emplean los vocablos en cuestión pueden considerarse terminológicos. Por lo demás, como han puesto de manifiesto desde los años 90 la socioterminología y la teoría comunicativa de la terminología, los textos especializados pueden presentar diferentes grados de especialización. Así, por ejemplo, los textos divulgativos son tan especializados como los científicos o técnicos creados para la comunicación entre expertos. La diferencia entre unos y otros radica en el nivel de complejidad comunicativa; $c f$. M. a Teresa CABRÉ, La terminología. Teoría, metodología, aplicaciones (Barcelona: Empúries, 1993) pág. 157. 
algunas voces son registradas, en el apartado dedicado a los «Nombres sustantivos» en la obra (págs. 3-30), bajo diferentes subapartados. Estos aluden a ámbitos designativos en el sentido ya empleado o a campos asociativos en el sentido de Bally ${ }^{42}$, como, por ejemplo, «De Dio» (pág. 3), «Estaciones y meses del año» (págs. 3-4), «Del tiempo» (pág. 4), «Del hombre y su parentera» (pág. 5 con términos como hombre, mujer, sobrino, sobrina, nono ['abuelo'], etc. ...», «Reinos y naciones» (pág. 30).

Un ejemplo puede verse en un extracto del capítulo sobre los nombres sustantivos/Hauptwörter, en la versión original (Fig. 1, supra) y en nuestra transcripción, a continuación:

II. Nombres sustantịvos:

Haupt-Wörter.

1. De Dio eĉt $[=$ etc.]. Got[t] ê̂t [=etc.].

Dios (Dio), Got[t]

el crịador, der Schöpfer

la crịación' [sic], dịe Schöpfụng

el ụnịverśo, das Weltal[1]

el mụndo, dịe Wịlt [sic]

el cielo, der Hịm[m]el

ụna crịatụra, eịn Geschöpf

la natụraleźa, dịe Natụr'

ụn espị'rịtu, eịn Geịst

ụn cụerpo, ein Kerper ụn planeta, eịn Planet'

" cometa, eịn Komet'

la lụź, das Lịcht

la tịniebla, dịe Fịnsternịs

el vịento, der Wịnd

ụna nụbe, eịne Wolke

el frịö, dịe Kälte

el calor', dịe Wärme

el rocịö, der Taụ

la $1[1]$ ụvịa, der Regen

" neḅla (duman), " Nebel

En este sentido, esta parte de la obra entronca con la tradición de las llamadas nomenclaturas ${ }^{43}$, que se remontan a los siglos $\mathrm{xV}$ y

42 Charles Bally, «Sur la motivation des signes linguistiques», Bulletin de la Société Linguistique de Paris 41 (1940) págs. 75-88 y «L'arbitraire du signe. Valeur et signification», FM (Le français moderne) 8 (1940) págs. 193-206.

43 Probablemente la obra de nuestro autor pueda enmarcarse en esta tradición de las nomenclaturas. Agradecemos a los evaluadores del artículo el habernos puesto en la pista de este tipo de obras como posibles fuentes y el habernos proporcionado otros valiosísimos datos y referencias para la elaboración de este trabajo. No obstante, se debe dilucidar todavía, en relación a los antecedentes de El Trajumán, cuáles fueron o pudieron ser sus fuentes inmediatas, puesto que no podemos olvidar que Papo habla de «libros de conversación» en las lenguas «española» y alemana. 
XVI ${ }^{44}$, y que, como señala García Aranda, pueden definirse como «breves repertorios temáticos bilingües y plurilingües que tratan de acercar el léxico de la lengua, siempre organizado en ámbitos designativos, a lectores que quieren aprenderlo de forma rápida y práctica. Los primeros que se elaboraron en la Península estaban redactados únicamente en español y latín, pero el paso del tiempo, las transformaciones políticas y sociales y la aparición de nuevas necesidades lingüísticas a partir del siglo XVI favorecieron la aparición de nomenclaturas de lenguas modernas y la desaparición paulatina del latín» ${ }^{45}$. Al igual que la obra de Papo, las nomenclaturas tenían como objetivo la enseñanza de lenguas extranjeras y, si atendemos a la distribución y caracacterísticas de la obra de Papo, saltan a la luz las similitudes estructurales que permiten relacionarlos 46 .

No ocurre lo mismo con las partes dedicadas a los «nombres adiectivos» (págs. 30-33) y a los «verbos» con las conjugaciones de los tiempos presente, pasado y «venidero» (págs. 33-42), donde parece haberse aplicado de forma asistemática cierto criterio de asociación semántica (sinonimia, antonimia, etc.) unido al criterio alfabético (orden alfabético del hebreo) a la hora de alistar el léxico de estas cate-

${ }^{44} C f$. Ayala Castro, «El concepto de nomenclatura», pág. 437, y Manuel Alvar Ezquerra, Las nomenclaturas del español. Siglos XV-XIX (Madrid: Liceus, 2013).

45 García Aranda, «La evolución de las nomenclaturas del español», pág. 89. Véase también su otro trabajo «Los diccionarios ideológicos, temáticos, de ideas afines y conceptuales», Estudios de Lingüística del Español 38 (2017) págs. 123-154: 124-125. Sobre la definición, la función, la estructura y las principales características de las nomenclaturas, véanse también los trabajos pioneros de Marta Concepción Ayala Castro, «El concepto de nomenclatura» o «Nomenclatures de l'espagnol (1526-1800): Considérations générales sur la nature et la fonction des nomenclaturas», Cahiers de Lexicologie 61:2 (1993) págs. 127-160 y, muy especialmente, los más exhaustivos de Manuel Alvar EZQUERRA como sus «Apuntes para la historia de las nomenclaturas en español», en Actas del VII Congreso Internacional de Lingüistica y Filología de América Latina (ALFAL). Homenaje a Pedro Henríquez Ureña, vol. 1 (Santo Domingo: Universidad Nacional Pedro Henríquez Ureña, 1987) págs. 457-470 o su extensa monografía, ya citada, Las nomenclaturas del español.

46 Véanse a este respecto los trabajos citados por GARCía ARANDA («La evolución de las nomenclaturas del español») como la Guía para la conversación en español e inglés de Emanuel del Mar de 1839. 
gorías ${ }^{47}$. Además del léxico especializado recogido en estas listas de palabras, también hemos considerado la abundante terminología que se ha extraído de la que hemos llamado «Guía de uso» (págs. I-XVI) y del resto de las partes, a saber, la que podría considerarse verdadera «Guía de conversación» (págs. 51-78), las «Recomendaciones al viajero» («Por atención») (págs. 79-88), que incluyen la guía de Viena, y el que hemos dado en llamar «Anexo» (págs. 89-96), con tablas alfabéticas de vocabulario empleado en la obra que requería de explicación (incluyendo la página de título y créditos) ${ }^{48}$.

Aparte de las unidades terminológicas, hemos extraído también las unidades que sirven de glosa a muchas de ellas. Estas, que constituyen en buena parte variantes sinonímicas de diferente índole, las hemos clasificado y analizado de acuerdo con su origen y función. Como el propio Papo indica, en su afán rehispanizador, se orienta, en numerosas ocasiones, en el español europeo peninsular de su época, pero es consciente de que los destinatarios de su obra pueden no conocer esas voces, por lo que, en estos casos, también les ofrece una variante judeoespañola patrimonial. Otras veces, parece emplear vocablos judeoespañoles que acompaña de otras formas de la misma variedad: variantes geográficas (diatópicas), estilísticas (diafásicas), sociales (diastráticas) (patrimoniales y tomadas en préstamo a otras lenguas), para ampliar las posibilidades expresivas del judeoespañol escrito.

47 También la nomenclatura de Emanuel del Mar estudiada por GARCÍA ArANDA («La evolución de las nomenclaturas del español», pág. 92) ordenaba algunos de los ámbitos designativos de forma alfabética, lo que, como señalaba la investigadora, hacía que se perdiera la ordenación interna no solo característica sino esencial de este tipo de obras.

${ }^{48} \mathrm{Si}$ comparamos la estructura y el contenido de la obra de Papo con la estudiada por García Aranda de Emanuel del Mar, publicada unos cuarenta años antes, salen a la luz las enormes semejanzas entre ambas, lo que permite retrotraerlas a una tradición común en la redacción de las nomenclaturas: «1) una primera parte que consta de unas indicaciones sobre pronunciación española redactadas en inglés, unas notas sobre pronunciación inglesa en español y el "Vocabulario de las voces más usuales" [...]; 2) una segunda parte que incluye una "Colección miscelánea de frases familiares y diálogos de etiqueta en español e inglés", y 3) una tercera parte que lleva por título "Colección de refranes y modos de decir, que más comúnmente se usan en la conversación"»; $c f$. García Aranda, «La evolución de las nomenclaturas del español», pág. 91. 
Para corroborar la existencia y el significado de los términos y variantes registradas, hemos hecho uso, fundamentalmente, de las siguientes obras lexicográficas: el Diccionario de la lengua española $(D L E)$, el Nuevo Tesoro Lexicográfico de la Lengua Española (NTLLE), los diccionarios de Nehama, Romano y el Diccionario Histórico del Judeoespañol (DHJE) ${ }^{49}$. Asimismo, hemos consultado también el Corpus Histórico del Judeoespañol (CORHIJE), además de los glosarios y listas de palabras en estudios que aparecen en estudios concretos ${ }^{50}$.

\subsection{Análisis terminológico}

La presentación de los términos, que se lleva a cabo por dominios especializados y seguirá el orden de aparición en la obra, irá acompañada de su(s) variante(s), dado el caso, la página o sección donde se encuentran y sus correspondencias en el español actual y comentarios, cuando sea necesario. Se destaca qué ámbitos especializados están más o menos representados, en qué áreas encontramos más variación y cuáles pueden ser las motivaciones.

Dado que son muchos los dominios especializados tratados en la obra y por limitaciones de espacio, para que sea posible hacerse una idea de la obra, de la presentación de la terminología y de cómo se realizó el análisis, nos centraremos aquí en dos ámbitos, a saber, Derecho / Administración / Economía (que se solapan muchas veces) así como Moda / Confección. Dejamos de lado otros ámbitos de especialización como, por ejemplo, Gramática / Ortografía / Fonética, Medicina, Alimentación y Botánica.

49 DLE; Nehama, Dictionnaire; Romano, Dictionary y el DHJE = Aitor García Moreno (dir.), Diccionario Histórico del Judeoespañol [en línea], <http://esefardic.es/ dhje> (última consulta: 22/07/2019).

${ }^{50}$ Como los trabajos de Quintana RodríGuez, Geografía lingüistica; Beatrice SCHMID e Yvette BüRKI, «El haćino imaǵinado»: comedia de Molière en versión judeoespañola. Edición del texto aljamiado, estudio y glosario (Basel: Romanisches Seminar der Universität Basel, 2000) y Elena Rieder-Zelenko, Novedades de Esmirna. Edición de noticias publicadas en el periódico judeoespañol «La Buena Esperanza» en 1905 (Barcelona: Tirocinio, 2013). 


\subsubsection{Derecho, Administración y Economía}

Identificamos 42 términos como pertenecientes al ámbito de Derecho / Administración / Economía. Ocho de ellos presentan variantes en, al menos, un caso de uso a lo largo de la obra:

- cinco casos de variedad diasistemática en judeoespañol; uno de ellos podría interpretarse como germanismo, lo que podría explicarse como la consideración de una variante diatópica, de Bosnia o de Viena;

- dos casos de probable rehispanización;

— un caso de rehispanización o palabra heredada.

Los elementos con variantes son los siguientes:

matrimonio (pág. 5, sin variante), matrịmonio: caśamiento (pág. 91) 'matrimonio, boda'

Curiosamente, matrimonio se recoge en la página 5 de la obra, pero más tarde, en la página 91 se aclara con la variante caśamiento. El motivo puede ser introducir una variante dialectal o una forma sinonímica no dialectal. Nehama recoge la voz como italianismo (pág. 351). Bajo kazamyénto (pág. 282) la voz se define como 'mariage'; no hay una entrada de la voz correspondiente en Romano. Por su parte, el DHJE registra ambas voces sin ningún tipo de marca.

dote (contado) (pág. 5) 'dote'

Romano recoge solo dote (pág. 133). Nehama no registra la voz; sí incluye, en cambio, kontádo que en la acepción del sustantivo significa 'dot payée en espèces' (pág. 301). Parece tratarse de un caso de rehispanización. En el NTLLE, no se encuentra, en ninguna referencia, una acepción en la que contado presente explícitamente el sentido de dote.

tutor (aptropos) (pág. 6) 'tutor'

La palabra aptropos, denominación hebrea para tutor, es de claro origen griego. El DHJE registra la voz apotropós con acentuación aguda con el mismo sentido. La voz glosada tutor puede ser o un caso de rehispanización o una palabra heredada.

bolsa (bersa) (pág. 14) 'bolsa'

En este caso, la referencia es la institución económica para la transacción de títulos valores $\left(c f\right.$. bolsa ${ }^{2}$ del $\left.D L E\right)$. La variante bersa podría explicarse 
como dialectal: en Nehama se recoge bórsa (pág. 96), pero el $D K W^{51}$ consigna berza, forma muy próxima a la que tenemos en nuestra obra. Curiosamente, el DHJE solo recoge la voz con el sentido de 'talega o saco que sirve para llevar algo'. Las ocurrencias en el CORHIJE aluden a este significado. Por su parte, bersa y berza no se encuentran ni en el DHJE ni en el CORHIJE. En croata encontramos burza ${ }^{52}$, en bosnio y serbo-croata berza. En Nehama se recoge bórsa (pág. 96). Podría explicarse como un caso de dos geosinónimos. Según Corominas ${ }^{53}$, la acepción 'casa de contratación' se recoge en 1646, proveniente del italiano borsa, lo que hace pensar que el uso de esta voz en Papo representa una rehispanización semántica, pues la forma parece acercarse a la serbo-croata.

confesar, atorgar (pág. 33) 'confesar'

Las formas atorgar y confesar aparecen en Nehama (págs. 67 y 297). La primera es, según el DLE, una forma antigua de otorgar. El NTLLE presenta 30 accesos. El primero de ellos recoge la referencia en el Diccionario de Autoridades $(1726$, pág. 472,1$)$, donde ya se indica que es voz anticuada y se relaciona geográficamente con Aragón. De la misma manera se pronuncian las abundantes fuentes que tratan de la forma en el DHJE (s.v.), donde solo se registra la forma con $a$-, más antigua. No se consigna otorgar, pero sí confesar (s.v.), que se relaciona como sinónimo con atorgar. Romano no recoge atorgar ni confesar. Podría tratarse simplemente de formas sinonímicas sin adscripción geográfica.

acusar (pág. 36, sin variante), acụ́ar: como aculpar (pág. 90) 'acusar'

Después de incluir, primero, acusar sin variante, en la pág. 90, -en un apartado en el que el autor aclara algunos términos que, según su opinión, no son conocidos por todos- vuelve a recoger la voz y la aclara como aculpar. El DHJE recoge las dos voces como sinonímicas, aunque para acuśar tiene dos entradas, un acuśar 1 que coincide con el significado de aculpar y otro acuśar 2 que significa 'objetar'. Resulta curioso que el autor indique que no todos conocen el significado de acusar, lo que permite la interpretación de que pueda tratarse de variantes geográficas.

${ }^{51} D K W=$ Marija UroIć y Anton Hurm, Deutsch-Kroatisches Wörterbuch. Mit grammatischen Angaben und Phraseologie (Zagreb: Školska knjiga, 2004).

52 Vid. DKW, pág. 122.

53 Joan Corominas, Diccionario etimológico castellano e hispánico. Vol. 1 (A-Ca). Con la colaboración de José Antonio Pascual (Madrid: Gredos, 2006 [1980]) pág. 618, s.v. bolsa. 
cvita (pág. 80, sin variante), cvita (recịbịda) (pág. 81) 'recibo'

Suponemos que cvita proviene del alemán Quittung 'recibo', por la aparente relación de las formas y ya que conserva precisamente la pronunciación [kv] inicial de la voz alemana. Nehama recoge el sustantivo resivíđa 'reçu, récépissé' (pág. 476). Llama la atención que la glosa que explica el préstamo del alemán no aparezca la primera vez que se utilizó la forma cvita en el texto (pág. 80). Por su parte, el DHJE no registra ni la voz cvita ni recịbịda. El germanismo apunta a la consideración de la variante de la variedad geográfica de Bosnia o Viena, es decir, estaríamos ante un caso de variación diatópica.

moneda de papel (banco-notas) (pág. 80) 'billete'

La glosa, banco-notas, parece ser traducción literal del alemán Banknote 'billete monetario'. Respondería a un caso raro de introducción de una forma nueva para acompañar una explicación, más que un término, ya que para moneda de papel el judeoespañol ya tenía billeto. Nota parece no haber tenido en judeoespañol el mismo significado que tiene el alemán Note ( $c f$. Nehama, pág. 385 y DHJE s.v. nota 1 y nota 2) y podría ser que nuestro autor desconociera que billete no se refiere solamente al billete de transporte, que sí menciona en diferentes ocasiones a lo largo de la obra. El mismo término moneda de papel podría ser un calco del alemán Geld in Scheinen 'dinero en billete' como término opuesto a Münzgeld 'dinero en moneda'. Interpretamos que banconotas es, potencialmente, un germanismo propio de las variedades bosnia o vienesa del judeoespañol, mientras que moneda de papel constituye un caso curioso de un calco aproximado (Lehnübertragung) ${ }^{54}$ del alemán.

\subsubsection{Moda y Confección}

Hallamos 28 términos del ámbito de Moda y Confección; 17 de ellos presentan variantes en al menos un caso de uso en la obra:

- seis casos de variedad diasistemática en judeoespañol;

- nueve casos de rehispanización;

- un caso interpretable como rehispanización o como formas heredada;

— un caso imposible de clasificar.

$54 C f$. Reinhard KIESLER, «La tipología de los préstamos lingüísticos: no sólo un problema de terminología», Zeitschrift für Romanische Philologie 109 (1993) págs. 505525: 509 y 513-514. 
Se trata de los siguientes casos:

sombrero (chapeau) (pág. 10) 'sombrero'

Nehama recoge chapeau como equivalencia francesa de la voz čapéo (acompañada por ejemplos con la grafía čapeo) (pág. 106) y Romano da «chapejo: chapeau, Hut» (pág. 110). Parece tratarse de un caso de variantes competitivas o dialectales, seguramente, habiendo ganado finalmente el préstamo francés. La palabra sombrero se recoge en Corominas como una innovación del castellano y el portugués y está datada ya en el Cid con el sentido moderno ${ }^{55}$. El $D H J E$ recoge sombrero y chapeo (con las variantes chapeyo, chapeyu) como sinónimos, aunque las fuentes que refieren chapeo son fundamentalmente orientales. También registra solombrero en el mismo sentido.

casaca (caput) (pág. 10) 'casaca'

Una casaca es, según el $D L E$, una «[v]estidura ceñida al cuerpo, generalmente de uniforme, con mangas que llegan hasta la muñeca, y con faldones hasta las corvas». Por la descripción que ofrece este diccionario parece tratarse de algo similar a un abrigo. Ni la voz principal ni la variante se hallan en el DHJE o en el CORHIJE. En Nehama aparece también kapót como «gros manteau, grosse cape d'hiver» (pág. 269). Esta voz recogida por Nehama y la variante a casaca que ofrece Papo están muy probablemente emparentadas con la voz capuz del francés, que, a su vez, proviene del italiano cappuccio, según el $D L E$ (s.v.) «vestidura larga y holgada con capucha y una cola que arrastraba, que se ponía encima de la ropa, y que servía en los lutos». Corominas ${ }^{56}$, por lo que respecta a casaca, dice que se trata probablemente de voz procedente del francés casaque y la primera documentación que encuentra es bastante tardía (en 1611, en Covarrubias). Esto nos hace pensar que se trata, de nuevo, de una rehispanización, aunque, como también se documenta esta palabra con significados al menos parcialmente coincidentes en otras lenguas como en francés (casaque), en alemán (Kasack) o en italiano (casacca), es difícil establecer el punto de partida real; es posible pensar en un caso de etimología múltiple ${ }^{57}$.

55 Joan Corominas, Diccionario etimológico castellano e hispánico. Vol. 5 (RI-X). Con la colaboración de José Antonio Pascual (Madrid: Gredos, 1983) pág. 299, s.v. sombra.

56 Corominas, Diccionario, vol. 1, pág. 903.

57 Tal y como indica Alexandru Graur en «Etimologie multiplă», en Studii de lingvistică generală. Variantă nouă (Bucureşti: Editura Academiei Republicii Populare Romîne, 1960) págs. 67-77 y en «Din nou despre etimologie multiplă», en Etimologii romîneşti (Bucureşti: Editura Academiei Republicii Populare Romîne, 1963) págs. 11-18. 
chaleco (vesta) (pág. 10) 'chaleco’

Estas voces no están en ninguno de los diccionarios judeoespañoles. Creemos que, en el caso de vesta ${ }^{58}$, debe tratarse originariamente de un préstamo del francés, proveniente de la forma femenina veste, que, a su vez, se tomó en el siglo XVII del italiano ${ }^{59}$. Este mismo origen se atribuye al vocablo alemán Weste $^{60}$ : «Der Name des Kleidungsstücks wurde im 17. Jh. aus dem frz. veste in dessen älterer Bed. „ärmelloses Wams“ entlehnt. Das frz. Wort selbst stammt aus it. veste „Kleid, Gewand“, das aus lat. vestis „Kleid, Gewand“ zurückgeht» ('El nombre de la prenda de vestir se tomó prestado del francés veste en su significado más antiguo de 'jubón sin mangas'. La palabra francesa procede, a su vez, del italiano veste 'vestido, vestimenta', proveniente del latín vestis "vestido, vestimenta"; la traducción es nuestra). Por su parte, en español puede rastrearse veste desde Nebrija (1495) hasta la actualidad, pero con los sentidos de 'vestido, vestimenta o vestidura'. A partir de 1780, el diccionario académico incluye la marca de «p.us.», «ant.» (1822) o «poét.» (1852). Estas mismas marcas se registran en otras fuentes lexicográficas recogidas en el NTLLE. El único dato curioso se nos presenta en Toro y Gómez (1901), que consigna vesta como sinónimo de veste. A su vez, bajo el lema vesta, en Sobrino (1705) se remite a veste y se señala «especie de camisote». No obstante, la prenda a la que se alude, camisote, no parece guardar relación alguna con veste 'chaleco', ya que se trataba de una prenda de la armadura cuyas mangas llegaban hasta las manos (cf. NTLLE, s.v. camisote). Por lo demás, en italiano existió la forma $v e s t a$, con el significado de 'vestido, vestimenta', pero Pianigiani (s.v. vesta $)^{61}$ indica lo siguiente: «dal lat. VESTIS, veste transportato alla prima declinazione (V. Veste). Ant. per Veste». Así, la terminación en - $a$ de vesta en Papo puede deberse a una analogía con la forma más corriente de creación de sustantivos

${ }^{58}$ La raíz indoeuropea ues-5 'vestir(se)' se halla en buena parte de esta familia lingüística: antiguo indio, griego, albanés, latín y gótico; cf. Julius PokornY, Indogermanisches etymologisches Wörterbuch (Bern-München: Francke, 1959 [1956]) entrada 2188, pág. 1172. De nuestro interés son las formas latinas vestis 'vestido' y vestire 'vestir', de donde provienen nuestra voz y otras tantas en las lenguas romances como en cast. vestido, vestimenta, etc. Pero también las formas germánicas got. wasjan, ahd. werian, aisl. veria 'kleiden', ags. werian, Kleider tragen; got. wasti 'Kleid'; mhd. wester 'Taufkleid' 'traje de bautizo', donde estaba abundantemente representada esta raíz.

59 Cf. TLFI, s.v. veste (TLFI = Trésor de la Langue Française informatisé, <http:// www.atilf.fr/tlfi> [última consulta: 28/09/2020].

60 Cf. Duden. Etymologie: Herkunftswörterbuch der deutschen Sprache (MannheimLeipzig-Wien-Zürich: Duden, 1997) pág. 811, s.v. Weste.

61 Ottorino Pianigiani, Vocabolario etimologico dalla lingua italiana. 2 Volume (Roma-Milano: Società editrice Dante Alighieri di Albrighi-Segati, 1907) pág. 1525. 
femeninos en castellano, pero resulta bastante plausible que nuestro autor haya tomado como modelo las voces de las lenguas de su entorno (serbio: вecma 'vesta'; rumano: vestă; checo: vesta; eslovaco: vesta. La palabra chaleco del español procede del turco ielék -en turco moderno yelek-, según informa Corominas ${ }^{62}$. También indica que la primera documentación es bastante tardía, de 1605 , por lo que es probable que chaleco sea una rehispanización.

capa, (jụbe) (pág. 10) 'abrigo'

Parece que se trata de variantes dialectales, siendo que la glosa es la forma oriental, pues es un turquismo que, según Nehama, se corresponde con la voz turca cuppe, cubbe 'sorte de toge, de vêtement de dessin en tissu mince pour homme, soutane' (pág. 238) y, según Romano, con un orientalismo cuyo significado explica mediante el alemán langer Überrock 'gabán largo' (pág. 188). La palabra capa data ya del año 952 según Corominas ${ }^{63}$. Este mismo autor especifica además: «El vocablo latino aparece por primera vez a fines del s. VI y en el viI, en Gregorio de Tours y en San Isidoro de Sevilla» y que «designaba un capucho u otra pieza empleada para cubrir la cabeza. De ahí debió pasarse a la capa provista de capucho y luego a cualquier capa». Por su parte, el DHJE recoge ambas voces como judeoespañolas y sinónimas. Consigna, además, testimonios que apuntan a la forma jube como orientalizante, así como otros sinónimos como cašaba, túnica y tonga.

botas (chiśmes) (pág. 10) 'botas'

En Nehama se recoge este turquismo čizméz con el significado 'botte à revers' (pág. 109) y en Romano no aparece. Es interesante que la palabra bota que incluye Nehama solo se registra con otros significados distintos a los que tenemos aquí: con los significados de 'tonneau' y de 'huche'. Esto nos hace pensar que la palabra sefardí era la de procedencia turca. Esta hipótesis la confirma Romano quien, en la entrada bota, solo consigna el significado de 'bouteille' (pág. 103). Igualmente, el DHJE (s.v.) confirma este aserto, pues recoge bota como 'tonel, barril'. Corominas ${ }^{64}$ dedica dos entradas distintas a la voz bota: la primera con el significado de 'vasija de cuero para beber vino', cuya primera documentación es de 1400 y la segunda 'especie de calzado' también documentado por primera vez en el 1400, en el Glosario de Toledo. Según informa Corominas ${ }^{65}$, es probable que la voz española proceda del francés o

62 Joan Corominas, Diccionario etimológico castellano e hispánico. Vol. 2 (Ce-F). Con la colaboración de José Antonio Pascual (Madrid: Gredos, 2007 [1980]) pág. 313, s.v. chaleco.

${ }^{63}$ Corominas, Diccionario, vol. 1, pág. 827.

${ }^{64}$ Corominas, Diccionario, vol. 1, s.v. bota.

65 Corominas, Diccionario, vol. 1, s.v. bota. 
catalán, si bien afirma no estar seguro de ello. Interpretamos bota como rehispanización.

medias (calzas) (pág. 10) 'medias'

En Romano no aparece ni medias ni calzas. En Nehama aparece kálsa con el significado de 'bas, chaussette' (pág. 263), pero no de 'medias'. El DHJE recoge calza pero no media, con el sentido de 'media'. Como sinónimos registra igualmente calcetín y el turquismo chorapág. Es muy interesante la información que aporta Corominas ${ }^{66}$ al respecto: «significó primeramente 'media' y procede del lat. vg. *CALCĚA, derivado del lat. CALCĚUs 'zapato'. 1.a doc.: Cid». Esto nos hace pensar que la palabra propiamente judeoespañola era calzas y que el caso de media debía tratarse de una rehispanización. Sobre la palabra media, Corominas ${ }^{67}$ nos aclara que se trata de la abreviación de media calza y las dataciones que recoge son de Mateo Alemán de 1599 y del Diccionario de Autoridades, que documenta un uso en 1605, con lo cual son bastante tardías. calzonịllos (zaragüeles) (pág. 10) 'braga'

Nehama recoge saragwéllos como 'culotte, braguette, grossièrement railées [sic]' (pág. 497), y también registra kalsón como 'culotte’ (pág. 263). En Romano se recoge saraguél como 'pantalon, sous-vêtement féminin, Unterhose für Frauen’ ‘braga para mujeres’ (págs. 291 y 201). Se trata de un caso de variación diatópica.

faltrịquera (pág. 10, sin variante), faltrịquera: halduquera (pág. 92) 'bolsillo'

En el glosario (pág. 92) aparece la forma faltrịquera glosada como halduquera. Corominas ${ }^{68}$ nos informa de que «es alteración de las formas antiguas y dialectales faldiquera y faldriquera, derivadas de faldica, forma diminutiva y amanerada de falda». La primera documentación de faldriquera la data en 1563, en Timoneda, y faltriquera, en 1570 en C. de las Casas. Son dataciones importantes ya que documentan que se dieron después de la expulsión de los judíos de la Península, lo que podría significar que estas formas no las llevaron consigo con el romance castellano que hablaban. Más adelante, nos aporta información sobre el judeoespañol: «en judeoespañol se oye haldiquera en Marruecos [...], aldiquera en Brusa y Constantinopla, y con sufijo -uca: falduquera en Salónica, Karafería, Monastir (también en salmantino), falduquera y falcudera en Bosnia...». Corominas explica que «la faltriquera es ante

${ }^{66}$ Corominas, Diccionario, vol. 1, pág. 770.

67 Joan Corominas, Diccionario etimológico castellano e hispánico. Vol. 4 (Me-Re). Con la colaboración de José Antonio Pascual (Madrid: Gredos, 2007 [1981]) s.v. media.

68 Corominas, Diccionario, vol. 2, pág. 842. 
todo la bolsa postiza que se ataban las mujeres del pueblo debajo de la falda», añadiendo que «aunque faltriquera se ha aplicado subsiguientemente a bolsillos masculinos, éstos son solamente [...] los dos bolsillos laterales de los calzones o pantalón, muy análogos a la faltriquera femenina, y nunca los bolsillitos delanteros o traseros del pantalón ni los de la chaqueta han llevado este nombre» (Corominas 2007, II: 842-843). Según Quintana Rodríguez ${ }^{69}$, «[e]1 judeoespañol heredó dos formas léxicas del español medieval, faldikera y faldukera; la primera derivada de faldica y las [sic] segunda derivada de falduca, formas diminutivas de falda...», y en castellano "se conservó faltriquera, forma que se desconoce en judeoespañol». Todo indica que nuestro autor está recastellanizando aquí.

collarịn' (yaca) (pág. 10) 'cuello' (en prendas de vestir)

La definición de collarín en el DLE - «Alzacuello de los eclesiásticos» y «Sobrecuello estrecho que se pone en algunas casacas»- parece estar bastante relacionada con el sentido que se recoge en Papo. Collarín no aparece ni en los diccionarios ni en las obras que han tratado el judeoespañol. En Romano aparece solo jaká con el significado 'col, collet, Kragen’ (pág. 196) y en Nehama, que le atribuye origen turco: «yaká (turc.) 'col, collet, faux-col'» (pág. 598). En el DHJE tampoco se registra collarín y yacá se incluye con el mismo sentido. En Corominas ${ }^{70}$, la palabra collarín figura como tomada del italiano collarino, datado en 1615 en Villaviciosa. La aparición de jaca en los diccionarios judeoespañoles así como la ausencia de collarín nos hacen pensar que la glosa es la palabra propiamente sefardí frente a la rehispanización.

ojal' (yelic) (pág. 10) 'ojal'

En Nehama aparece la palabra yelék como turquismo con el significado en francés 'gilet' (que equivaldría a esp.jileco) (pág. 601). Ni la palabra hispana ojal ni el turquismo yelik aparecen en Nehama. En Romano encontramos ilik como 'ojal, boutonnière, Knopfloch' (pág. 194), pero tampoco se incluye ojal. Si buscamos en un diccionario de español-turco bajo ojal encontramos $i_{i k}{ }^{71}$. Así lo confirma también Miklosich quien recoge iliḱ como 'Knopfloch, Schlinge, Schleife' (pág. 70) ${ }^{72}$. La información aportada por los diccionarios de turco, así

${ }^{69}$ Quintana Rodríguez, Geografía lingüistica, pág. 189.

70 Corominas, Diccionario, vol. 2, pág. 270.

${ }^{71}$ GDET = İnci KUT y Güngör KUT, Gran diccionario español-turco. Büyük Ispanyolca-Türkçe sözlük (Istanbul: Inkilap, 2006) pág. 553.

72 Franz Miklosich, Die türkischen Elemente in den südost- und osteuropäischen Sprachen (Wien: Buchhändler der kais. Akademie der Wissenschaften, 1884) pág. 75. Agradecemos a los evaluadores de este artículo el habernos advertido de esta referencia bibliográfica. 
como la voz española y la alemana nos muestran que Papo no entiende la voz yeliq como chaleco en el sentido de la voz francesa gilet, como indica Nehama, sino como 'hendidura ordinariamente reforzada en sus bordes y a propósito para abrochar un botón, una muletilla u otra cosa semejante' (DLE, s.v. ojal). Corominas ${ }^{73}$ recoge la palabra ojal en Covarrubias (1611). En cualquier caso, estamos ante una rehispanización frente una voz patrimonial.

forro, (astar) (pág. 10) 'forro, entretela'

Forro no aparece en Romano, mientras que astar sí se incluye como 'doublure, Futter (im Kleid)’ (pág. 84). En Nehama forro se registra como «libre, affranchi, libéré de l'esclavage (Ladino)» (pág. 215), pero astar no aparece. En el GDET bajo forro se encuentra el significado 'astar' (pág. 345) y en el trabajo de Steuerwald ${ }^{74}$ bajo al. Kleiderfutter -literalmente, 'forro de ropa'- se da el significado 'astar'. En la glosa tenemos nuevamente un turquismo, voz que probablemente era la más usual, tal y como se desprende de su aparición en los diccionarios de judeoespañol ${ }^{75}$. En el $D H J E$ se recogen ambas formas como sinónimos. Podría ser que forro fuera una rehispanización si tenemos en cuenta la información que aporta Corominas ${ }^{76}$ al respecto: «En cuanto al sustantivo forro, es tardío [1599, Guzmán de Alfarache], y un poco antes se halla enforro [invent. Arag. de 1465, Pottier; Nebr.] o aforro [Timoneda]», y concluye: «de suerte que no hay duda de que es postverbal y no descendiente directo del germ. Fôdrm como ocurre también en el cat. mod folro, port. forro o forra, it. Fòdera, forro». Sin embargo, el hecho de que ambos vocablos aparezcan en fuentes judeoespañolas podría hacer pensar que se trata o bien de variantes geográficas o bien de «variantes diacrónicas» debidas al afán rehispanizante de Papo que lo lleva a sustituir el turquismo patrimonial del judeoespañol por la variante rehispanizante.

gụantes (maneras) (pág. 10) 'guantes'

En Romano no está ni guante ni manera en el sentido que aquí recoge Papo ('manière, façon, Art und Weise'). En Nehama se encuentran tanto gwánte con el significado de 'gant' como manera que tiene como segunda acepción 'gant (pour la main)’ (pág. 232). El DHJE recoge ambas formas como sinonímicas

${ }^{73}$ Corominas, Diccionario, vol. 4, pág. 273.

74 Otto Steuerwald, Deutsch-Türkisches Wörterbuch (Wiesbaden: Otto Harrassowitz, 1987) pág. 234.

75 En búlgaro existe la forma хастар como 'Futterstoff' 'tela para forros' en el campo de la moda y la vestimenta (Langenscheidt. Bulgarisch-Deutsch [en línea], $<$ https://de.langenscheidt.com $>$ ). Este es un testimonio interesante, ya que implica que no necesariamente es una variante diacrónica.

76 Corominas, Diccionario, vol. 2, s.v. forrar. 
(también gante, manigueta), aunque por los testimonios que presenta parece que es más usual manera. Maneras sería un neologismo sefardí, pluralia tantum que significa 'guantes', formado sobre el sustantivo mano y el sufijo -eras, recogido por Pipano en su Diccionario judeo-español-búlgaro ${ }^{77}$. Podría pensarse, por tanto, en el uso de variantes sinonímicas que reflejan alguna variedad dialectal, ya sea diatópica o diastrática.

chịnelas (pág. 10, sin variante), chịnelas (zapatos de caśa) (pág. 53), chinelas: zapatos que se llevan en caśa (pág. 90) 'pantufla'

Resulta curioso que en la entrada principal no aclare el término, cuando, a todas luces $-\mathrm{y}$ el hecho de que lo explique más tarde así lo indica-, no parece ser una voz conocida por todos. En los diccionarios de judeoespañol no aparece. En el $D L E$ aparece definido como «1. f. Calzado a modo de zapato, sin talón, de suela ligera, y que por lo común solo se usa dentro de casa». Corominas ${ }^{78}$ da «Chinela, del antiguo chanela íd., y éste probablemente de cianella, forma dialectal, al parecer genovesa, del it. pianella íd., diminutivo de piano 'plano, llano', procedente a su vez del lat. PLANUs: se explica este nombre porque las chinelas se distinguían de los chapines y demás calzado por su falta de tacón. 1 doc.: Apal., 43d, 96d [= Alonso Fernández de Palencia, Vocabulario en latin y romance, Sevilla 1490]». Si bien chinelas, por esta datación, en teoría podría formar parte del acervo hispánico del judeoespañol, en vista de la falta absoluta de documentación en los diccionarios, descartamos esta opción. En el caso de chịnelas, se trata, muy probablemente, de una rehispanización, si bien no puede excluirse del todo la posibilidad de que la forma sea una variante diasistemática, quizá diatópica, de zapatos de caśa. Por otro lado, zapatos de caśa podría ser una explicación o reformulación explicativa, lo que resulta aún más probable si vemos la construcción «zapatos que se llevan en caśa» (pág. 90).

pañelo (reźa) (pág. 10) 'pañuelo'

$\mathrm{Ni}$ en Romano ni en Nehama está pañelo ni tampoco pañuelo (solo pañal y paño), pero tampoco la palabra que aparece en nuestro texto entre paréntesis. Quintana Rodríguez ${ }^{79}$ menciona que en las comunidades sefardíes de Turquía, Bulgaria e Israel se mantiene el elemento de origen turco ridá, que, en Bosnia, Serbia, Macedonia, Norte de Grecia y Esmirna aparece como rizá, forma muy parecida a la que tenemos en nuestro texto por haber entrado directamente del

77 Albert Pipano, Diccionario judeo-español-búlgaro (Sofía: Nades̀da, 1913), a partir de la edición de Dora Mancheva, El Diccionario judeo-español - búlgaro de Alḅert Pipano: edición y estudio (Tesis doctoral inédita, Genève: Université de Genève) págs. 87, 115, 556 y 670.

78 Corominas, Diccionario, vol. 2, pág. 364.

79 Quintana RodríGuez, Geografía lingüistica, pág. 265. 
serbio, si bien también hay formas parecidas en búlgaro y albanés. Por su parte, el DHJE registra pañuelo y tanto ridá como riźá como sinónimos, aparte de destemel, mehermá y tavayol. La palabra pañuelo entra en el español en época tardía, según nos informa Corominas. Sobre la diptongación de este vocablo encontramos información interesante en Corominas ${ }^{80}$, que permite excluir la posibilidad de que pañelo sea un elemento anterior a la expulsión de los judíos de la Península ${ }^{81}$. La tardía incorporación del vocablo pañuelo y la ausencia de diptongación nos hacen pensar que Papo está utilizando la palabra hispánica que no conoce bien y que la glosa con la palabra que, a su juicio, se entendía en otras variedades u otros lugares. Es, claramente, un caso de variación diasistemática y de rehispanización.

gorro (capa) (pág. 10) 'gorro'

En Nehama no encontramos gorro -que Papo, en su afán rehispanizante, escribe con doble reš-, pero sí kápa con el significado de 'cape, manteau' (pág. 268), de modo tal que no coincidiría con el significado que parece querer atribuirle Papo, si tenemos en cuenta el vocablo alemán correspondiente, Mütze 'gorro', con el que lo traduce. Nehama recoge el fraseologismo venir kon su kapa y su bonete con el significado de 'hacer una proposición deshonesta a alguien' (pág. 268), y aclara al final de la explicación que «la cape et le bonnet étaient les insignes des universitaires, des gens de haute culture.)». Romano lo traduce al francés como bonnet y al alemán como Mütze (pág. 204), tal y como lo especificaba Papo, pero gorro no aparece en su obra. Pese a que la palabra en la glosa capa podría llevarnos a confusión por su confluencia con la palabra del español general capa, se trata muy probablemente de un término de origen balcánico presente en búlgaro y bosnio con el significado que aquí tenemos de 'gorro' 82 .

80 Corominas, Diccionario, vol. 4, pág. 380.

81 Señala Corominas (Diccionario, vol. 4, pág. 380) que «[c]omo -ŎLUs, con su resultado -uelo, es un sufijo históricamente sólo posible tras un hiato de $\breve{l}$ o $\breve{e}$ en latín, se comprende la fecha tan tardía de pañuelo, que sólo desde hace unos 300 años empieza a sustituir a su antecesor pañizuelo, cuando ha muerto toda la reminiscencia de que la $\tilde{n}<\mathrm{NN}$ era una consonante tras la cual no era posible -uelo; y así se comprende que el vocablo no tenga hermanos en ninguna lengua romance y sea ajeno aun al catalán (mocador) y al portugués (lenço) y gallego, que emplea pano de nariz (Castelao 282.2) o paniño: «enxoitan as bágoas con paniños de encaixe» (íd. 163.19)».

82 Este balcanismo ha sido recogido y estudiado por Dora MANCHEva en «Los rastros del búlgaro en la parte judeoespañola de un diccionario trilingüe francés-búlgarosefardí», Cuadernos del Instituto Historia de la Lengua 1 (2008) págs. 75-86: pág. 82, según la cual, aunque la palabra existe también en turco, es «común al ruso, croata y polaco, y emparentada con lat. CAPPA, CAPUT». 
Por otra parte, Corominas ${ }^{83}$ recoge gorro con el significado de 'bonete redondo' en Autoridades y la primera concordancia en el $C O R D E^{84}$ data de 1550 , por lo que es bastante tardía. Parece que estamos claramente ante un caso de rehispanización, es decir, que el préstamo de origen balcánico es el propiamente usado en judeoespañol y gorro el elemento usado por el afán del autor de rehispanizar. En parte, esto parece también corroborarlo el DHJE, que no registra gorro, pero sí dos entradas de capa, aunque ninguna parece cubrir íntegramente el sentido que tenemos en nuestro texto. Así, en capa 1, la definición es 'envoltorio, cobertura', mientras que en capa 2 tenemos 'capa, prenda de vestir' y se la considera sinónima de $\hat{j} u b a$, entre otros.

corsé' (copča) (pág. 10) 'corsé'

Corsé no se registra en la mayoría de los diccionarios de judeoespañol. Nehama incluye korsé indicando el significado 'corset' (pág. 305). Resulta curioso que la voz copča no se halle registrada. Se trata con toda probabilidad de un turquismo. Así lo considera el DHJE que consigna la palabra copchá como 'corchete, broche' y ofrece como sinónimos alfiler, alfinet, broch. Sin embargo, estos sentidos claramente no se corresponden con el que tenemos en la obra. ¿Habrá confundido Papo los términos? Si es que efectivamente se equivocó o desconoció el término, no podría clasificarse, ya que, si no lo conocía, es extraño que quisiera rehispanizar.

chinta (kayịs) (pág. 11) 'cinta, cinturón'

Posiblemente se trata de un italianismo, del it. cinta; cast. cinta, cinto, cinturón. En Nehama encontramos «kayíš (turc).-S. m. = I. 'lanière, courroie, sangle'. 2. 'bride, rêne'» (pág. 280); Romano, sin embargo, no lo menciona. En Steuerwald encontramos el equivalente kayış (pág. 270). Los equivalentes franceses que nos ofrece Nehama pueden hacer referencia a una cinta, banda o correa, si bien tanto courroie como sangle pueden ser también equivalentes de cinturón. También así lo indica la palabra alemana correspondiente a la voz turca, Gürtel. Excluimos el segundo significado mencionado por Nehama, pues daría algo como esp. rienda que no se ajusta a lo que encontramos para la forma turca. Por ello, interpretamos la glosa dada por Papo como un caso de variación diasistemática, probablemente, diatópica.

83 Corominas, Diccionario, vol. 3, s.v. gorro.

${ }^{84}$ CORDE $=$ Real Academia Española, Corpus diacrónico del español, <http:// corpus.rae.es/cordenet.html> (última consulta: 22/04/2020). 


\section{RESUltados Y VALORACIÓN FINAL}

En el caso de los términos jurídicos o económicos, pudimos constatar que, cuanto mayor es el grado de especialización, menor es la incidencia de variantes, puesto que, en muchos casos, ni siquiera existen en el ámbito patrimonial del judeoespañol: es decir, son elementos tomados prestados o en el camino de los judíos de España por Italia, o de las lenguas habladas en el Imperio Otomano o de las lenguas nacionales de los países que surgieron tras su desintegración. Por lo demás, encontramos casos de rehispanización que, probablemente, el autor quería introducir conscientemente y que proceden de las lenguas de cultura de los sefardíes, como el hebreo, el alemán, el italiano y el francés.

En el caso de los términos relacionados con la moda y confección, puede comprobarse que, al tratarse de términos de uso menos técnico, de un menor grado de especialización, el número de variantes es mayor. Un buen número de las variantes incluye voces que hemos clasificado de rehispanismos en competencia con otras voces que parecen ser parte del fondo patrimonial judeoespañol. En total, entre los préstamos en el campo de la moda y confección, se observa un claro predominio de los de origen turco, lo cual no es de extrañar, pues nos encontramos en Viena en la época del Imperio Otomano y además esta fue la lengua de buena parte de la cultura material judeoespañola. También es cierto que cabe mencionar que encontramos voces francesas e italianas. Por lo tanto, vemos reflejado el hecho de que el italiano y el francés han tenido un peso especial en el desarrollo del judeoespañol debido al papel de estas lenguas en las comunidades sefardíes como lengua de escolarización y del comercio y, en el caso del italiano, también por el paso por Italia de los judíos expulsados. El alemán tiene una importancia particular, probablemente explicable debido a la variedad diatópica del propio autor y a la finalidad de esta guía, que no es otra que enseñar alemán a los sefardíes que estén en Viena.

El análisis tanto cuantitativo como cualitativo de las variantes resulta muy revelador si tenemos en cuenta las diferentes vertientes en el tratamiento de los vocablos por los distintos autores de la época y nos permite determinar que Papo se mueve entre una clara tendencia recastellanizadora del judeoespañol escrito culto, por una parte, y una palmaria inclinación por usar las variantes diatópicas, diastráticas, diafásicas para dotar los textos de mayor número de términos «autóctonos» y darle al 
judeoespañol una mayor flexibilidad y fuerza de expresión en contextos que antes no constituían dominios de uso del judeoespañol. Nótese que, tal y como había señalado Schmid ${ }^{85}$, la obra de Papo se sitúa en la época de plenitud del judeoespañol en la que este ya estaba conformado como tal y era capaz de asumir todas las funciones comunicativas que exigiera su comunidad. Se refleja, por tanto, la ideología lingüística del autor en los diferentes glosarios incluidos en la obra.

Otro aspecto importante es el hecho de que una observación pormenorizada de los diferentes dominios especializados revela que, en el judeoespañol del siglo XIX, pueden atestiguarse muchos términos para denominar realidades modernas, introducidas para adaptarse a las nuevas exigencias de un mundo cada vez menos aislado y más cohesivo. Si bien para los estudiosos del judeoespañol no resulta sorprendente, es otra prueba más de que es totalmente errónea la presentación del judeoespañol como variedad medieval prácticamente fosilizada, como se puede leer todavía en manuales introductorios de lingüística románica o hispánica ${ }^{86}$. También en el judeoespañol de Viena, que se encontraba en una situación de contacto lingüístico diglósica, pero nada periférica respecto de las demás comunidades sefardíes, se constata el interés por renovar y modernizar el léxico, ciertamente con todos los mecanismos neológicos posibles, destacando los préstamos de otras lenguas, los calcos semánticos, la formación de palabras con material autóctono e hibridizaciones entre elementos judeoespañoles y elementos tomados o de otras lenguas o de otra variedad hispánica.

El glosario es tan interesante para la lexicología del judeoespañol y, con ello, para la lexicología del español en general, por contener muchos elementos sin duda alguna diasistemáticamente marcados, a diferencia de lo que se da en muchos textos impresos conservados de la misma época.

Recibido: $27 / 04 / 2020$

Aceptado: 02/10/2020

85 SCHMID, «La lengua sefardí en su plenitud», págs. 52-53.

86 Véanse, por ejemplo, los manuales de Vicente García De Diego, Manual de dialectología española (Madrid: Espasa Calpe, 1946) y de Manuel Alvar López, (ed.), Manual de dialectología hispánica, vol. 1 (Barcelona: Ariel, 2016 [1996]) págs. 341-377. 
